FIU Law Review

Spring 2013

\title{
Navigating the Gap: Reflections on 20 Years Researching Gender Disparities in the Legal Profession
}

\author{
Joyce S. Sterling \\ University of Denver Sturm College of Law \\ Nancy Reichman \\ University of Denver
}

Follow this and additional works at: https://ecollections.law.fiu.edu/lawreview

Part of the Other Law Commons

Online ISSN: 2643-7759

\section{Recommended Citation}

Joyce S. Sterling \& Nancy Reichman, Navigating the Gap: Reflections on 20 Years Researching Gender Disparities in the Legal Profession, 8 FIU L. Rev. 515 (2013).

DOI: https://dx.doi.org/10.25148/lawrev.8.2.16

This Article is brought to you for free and open access by eCollections. It has been accepted for inclusion in FIU Law Review by an authorized editor of eCollections. For more information, please contact lisdavis@fiu.edu. 


\title{
Navigating the Gap: Reflections on 20 Years Researching Gender Disparities in the Legal Profession
}

\author{
Joyce S. Sterling \& Nancy Reichman*
}

\section{THE CONTEXT}

The facts are consistent and conclusive. Although women have made some gains in the practice of law, they lag behind men in the numbers going to law school, entering the profession, career earnings, and advancement. Thus, perhaps not surprisingly, they are more likely to leave law practice than men.

Compensation - Women lawyers continue to earn less than men; an unwavering finding across most studies of the profession. The evidence for the gender gap in earnings includes findings from the only national, longitudinal study of lawyers in the United States, After the JD (hereinafter "AJD"), panel studies of elite law schools, ${ }^{1}$ and state level surveys. Considering only at AJD, the most comprehensive look at earnings, women earned five percent less than men, on average, after only three years of practice. ${ }^{2}$ After seven years, the gap between men and women's earnings had grown to thirteen percent.

The Pipeline - Between the 1980's and 2009, the percentage of women graduating from law schools increased from $40 \%$ to $48 \%$, although this varies by region. In some of the less populated areas, the Law School Admissions Council reports that women represent only

* Joyce S. Sterling is Professor of Law at the University of Denver Sturm College of Law. Nancy Reichman is Professor of Sociology and Criminology at the University of Denver.

1 Kenneth G. DauSchmidt, Marc S. Galanter, Kaushik Mukhopadhaya, \& Kathleen Hull, Men and Women of the Bar: The Impact of Gender on Legal Careers, 16 MICH. J. GENDER \& L. 49 (2009) (studying the careers of University of Michigan law graduates).

2 Ronit DinOVitzer, Bryant GARTH, RiCHARD SANDER, JOYCE STERLing, \& GitA Wilder, NAlP Found. \& Am. BAR Ass'N, After the JD: ThE First Results of A NATIONAL STUdy OF LEGAL CAREERS 58 (2004) [hereinafter AJD I].

3 Ronit Dinovitzer, Robert L. Nelson, Gabriele Plickert, Rebecca SAndefur, \& JoYCE S. STERling, AM. BAR Found. \& NALP FOUnd. FOR LAW CAREER Res. \& EDUC., After the JD: Second Results from a National Study of Legal Careers 67 (2009) [hereinafter AJD II].

4 Press Release, NALP, Representation of Women Among Associates Continues to Fall, Even as Minority Associates Make Gains (Dec. 13, 2013) (on file with authors). 
$40 \%$ of first year law students. ${ }^{5}$ The representation of women in law schools reached its peak in 1993, when women made up more than $50 \%$ of first year enrollment in law schools. ${ }^{6}$ The proportion of female applicants has declined in recent years. ${ }^{7}$ In 2011, women accounted for $46.8 \%$ of entering law students, a decline the NALP reports may have begun seven to eight years before. ${ }^{8}$ Although the percentage of women law students declined, the percentage of women in the associate ranks of law firms remained relatively stable, at least through 2009.' Beginning in 2010, and through 2012, the percentage of women associates began a small, but continuous decline $(45.41 \%, 45.35 \%$, and $45.05 \%$ respectively). ${ }^{10}$

Exits - Women are more likely than men to leave the practice of law. ${ }^{11}$ Their exits begin early and accelerate over time. ${ }^{12}$ Women are more likely to leave law firms before partnership decisions are made. Studies also indicate that women are more likely than men to search for new employment outside the legal profession. ${ }^{14}$ Very few studies are able to document what factors lead women to decide to exit their positions.

$5 \quad$ Id.

6 Hollee Schwartz Temple, Clogged Pipeline: Lack of Growth at Firms has Women Skipping Law School, A.B.A. J., Oct. 2012, at 29.

$7 \quad$ Id.

8 NALP Found., Update on Associate ATtrition: Findings From a National Study of LAW Firm AsSOCIATE HiRING AND DEPARTURES, CALENDAR YEAR 20117 (2012).

$9 \quad$ Press Release, supra note 4.

10 Id.

11 See, e.g., R.L. Hirsch, Will Women Leave the Law?, 16 BARRISTER 22 (1989); Carrie Menkel-Meadow, Exploring a Research Agenda of the Feminization of the Legal Profession: Theories of Gender and Social Change, 14 LAW \& SOC. INQUIRY 289 (1989). For a description of one person's account of the decision to leave law practice, see Mary Otvos, Why I'm Leaving Law, CANAdian LAW., Feb. 1992, at 12.

12 Barbara Flom, Report of the Seventh Annual NAWL National Survey on Retention and Promotion Women in Law Firms, NAWL \& NAWL FOUNDATION, Oct. 2012, at 8-9 [hereinafter NAWL 2012]. The NAWL Survey reports that the majority of staff attorneys are women, the only lawyer category where this is so. Staff attorneys are not on the partnership track.

13 Nancy J. Reichman \& Joyce S. Sterling, Recasting the Brass Ring: Deconstructing and Reconstructing Workplace Opportunities for Women Lawyers, 29 CAP. U. L.R. 923, 929 (2002) [hereinafter Recasting].

14 For additional studies finding women leaving the legal profession see Joan Brockman, Leaving the Practice of Law: the Wherefores and the Whys, 32 ALTA. L. REV 116, 123 (1994); Hirsch, supra note 11; Fiona M. Kay, Flight From Law: A Competing Risks Model of Departures from Law Firms, 31 LAW \& SoC'Y REV. 301, 302 (1997); Fiona M. Kay, Crossroads to Innovation and Diversity: The Careers of Women Lawyers in Quebec, 47 McGill L.J. 699 (2002); Fiona M. Kay \& John Hagan, Building Trust: Social Capital, Distributive Justice, and Loyalty to the Firm, 28 LAW \& SOC'Y INQUIRY 483, 510 (2003); Carrie Menkel-Meadow, Exploring a Research Agenda of the Feminization of the Legal Profession: Theories of Gender and Social Change, 14 LAW \& SOC'Y. INQ. 289 (1989). 
Advancement - In 1993, the first year published, comparable, aggregate data were available, the National Association of Law Placement reported that women made up $12.27 \%$ of partners. ${ }^{15}$ Women have made small incremental gains in the ranks of partnership since then. By 2009 , women represented $19.21 \%$ of all partners, ${ }^{16}$ clearly not a very close representation of women who passed the bar and with sufficient tenure in the profession to be eligible for promotion. Arguably, the momentum has stalled. In 2010, 2011, and 2012, women made up $19.43 \%, 19.54 \%$, and $19.91 \%{ }^{17}$ respectively of partners in law firms as reported by the NALP Directory of Legal Employers (NDLE). Scholars of the legal profession find similar, dramatic disparities in promotion rates of women as compared to those of men across a vast array of studies.

This paper reflects on our work and findings about gender disparities in earnings, as well as the substantial literature created by other scholars in the field, to assess where we are and where we need to go to navigate the gap. Over the last two decades, we have conducted in-depth studies of Colorado lawyers and analyzed data from the AJD national survey. In each study, we identified a bit of new information about earnings, unavailable to us during the data gathering phase of the previous projects, to help explain the persistence of earning disparities. ${ }^{19}$ We assumed that if only we could identify and collect the right piece of information, we would be able to unlock the persistent problems of gender disparity in law. Now, almost 20 years later, we are still discussing gender disparities, hidden biases, the challenges of work-family integration and, most importantly, still thinking of our

15 Press Release, supra note 4.

16 Id.

17 Id.

18 For findings about promotion rates of firms allowing part-time or parental leave, see Elizabeth Chambliss, Organizational Determinants of Law Firm Integration, 46 AM. U. L. REV. 669, 728-29 (1997); Elizabeth Gorman, Work Uncertainty and the Promotion of Professional Women: The Case of Law Firm Partnership, 85 SOC. ForCES 864, 877 (2006). For additional support from a study of Toronto lawyers, see JOHN HAGAN \& FIONA KAY, GENDER IN PRACTICE: A STUDY OF LAWYERS' LIVES $73-95$ (1995). For additional findings from the study of Canadian lawyers see, Fiona Kay \& John Hagan, Raising the Bar: The Gender Stratification of Law Firm Capitalization, 63 AM. Soc. REV. 728, 739 (1998) [hereinafter Raising the Bar]; Fiona Kay \& Elizabeth Gorman, Women in the Legal Profession, 4 ANN. REV. LAW \& SoC. SCI. 308, 308-11 (2008). For an analysis of the University of Michigan graduates see, M.C. Noonan \& M. Corcoran, The Mommy Track and Partnership: Temporary Delay or Dead End?, 596 ANN. AM. ACAD. POL. \& SOC. SCI. 130, 146-49 (2004).

19 The authors have jointly or individually been involved in three different studies of lawyers: the study of Colorado lawyers (referred to as Gender Penalties and Gender Penalties Revisited), After the JD (the first national longitudinal study of lawyers in the U.S.), and Nancy Reichman, From 1L To 401k: A Pilot Study of the Later Stages of Lawyers' Careers, LSAC GRANTS REPORTS SERIES (Mar. 2011). 
journey as just one step away from meaningfully eliminating the gap. We have been able to document that women lawyers are valued less than men. However, we have been less successful in exposing the black box of compensation and promotion to empirically demonstrate the more invisible and subtle sources of bias that we first identified decades ago. We continue to be hopeful. Field research that allows us to continue our search for the elusive clues would be helpful. Even more so would be women lawyers' collective insistence for transparency in decision-making that will be necessary to affect change.

\section{OUR BEGINNINGS}

In 1994, the Colorado Bar Association, in cooperation with the Colorado Women's Bar Association, published one of their periodic economic surveys of reported earnings of lawyers in the Denver community. ${ }^{20}$ For the first time, the study analyzed earnings by gender and showed a significant disparity between men and women, even controlling for the amount of time practicing law. The average woman working full-time earned only fifty-nine cents to the dollar earned by the average man working full-time. ${ }^{21}$ While some earnings difference was expected, the Colorado Women's Bar was surprised and concerned by the size of the gap and formed a committee to study the results and identify remedies. We were invited to join the committee along with a number of prominent women and men from the legal community. After months of significant discussion, the group agreed that research oriented to the mechanisms that produced the gap, not simply more research that documents it, was a necessary first step. We were commissioned to conduct an in-depth case study of the careers of lawyers in the Denver area to examine the evolution of careers and locate where gender biases might be found. We began the project, along with attorney Cathlin Donnell, naively expecting that we would be able to expose the sources of bias, make recommendations, and move forward to remove the barriers to women's success in law.

20 COLO. WOMEN's BAR Ass'N., A REPORT OF THE CBA 1993 ECONOMIC SURVEY AS IT

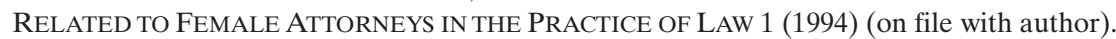

21 When tenure in law was introduced as a control, the significant gap in income remained unchanged. Women with one to three years' experience averaged $82 \%$ of the income of comparable men; women with four to nine years experience averaged $86 \%$ of the average income of comparable men; women with ten to twenty years experience earned only $76 \%$ of the average income of comparable men. At the time of the survey, there were too few women with more than 20 years experience to compare to the most senior males. See Nancy J. Reichman \& Joyce S. Sterling, Sticky Floors, Broken Steps and Concrete Ceilings in Legal Careers, 14 TEX. J. WOMEN \& L. 28 (2005) [hereinafter Sticky Floors]. 
We located our early scholarship, theoretically, within the construct of the gendered organization. ${ }^{22}$ A gendered organization is not necessarily populated predominately by men. Rather, it is an organization defined, conceptualized, and structured in ways that puts a premium on masculine characteristics, including a willingness to work "on demand," free from domestic responsibilities. ${ }^{23}$ Gendered organizations are infused with stereotypes about the appropriate roles for men and women that create roadblocks to slow or prevent upward mobility of women to positions of power within them. ${ }^{24}$ Performance evaluations in these organizations are gendered ${ }^{25}$ creating double standards and impossible criteria for women to meet. Our Colorado interviews, for example, revealed that men were evaluated on the basis of their "recognized potential," while women had to prove their worth according to measurable indicators. ${ }^{26}$ To be clear, a gendered organization is not an organization where men sit around conspiring how they can exclude women from the workplace. Even in gendered organizations, management may aim to increase the number of women in the workplace but throw up their hands, rather than contemplate change, when the women they recruit decide to move to other work organizations or drop out of the labor market because work structures and culture are inhospitable to them. ${ }^{27}$

The understanding that law firms are gendered organizations was not unique to our research, of course. Jennifer Pierce's study of litigators and their paralegals had already exposed a symbolic macho culture among male litigators. ${ }^{28}$ Robin Ely discovered that firms domi-

22 Joan Acker, Hierarchies, Jobs, Bodies: A Theory of Gendered Organizations, 4 GENDER \& SOC'Y 139 (1990).

23 See JoAn Williams, Unbending Gender 64 (2000); Dana M. Britton, The Epistemology of the Gendered Organization, 14 GENDER \& SOC'Y 418 (2000). For additional research on gendered organizations see ANN GAME \& RosemARY PRINGLE, GENDER AT WORK (London: Pluto Press 1984); Joan Acker, Gendered Institutions: From Sex Roles to Gendered Institutions, 21 CONTEMP. SoC. 565 (1992); Joan Acker, Gendering Organizational Theory, in GENDERING Organizational AnAlysis (Albert J. Mills \& Peta Tancred eds., 1992). For a more recent treatment of gendered organizations see, Cecilia L. Ridgeway, Framed Before We Know It: How Gender Shapes Social Relations, 23 GENDER \& SOC'Y 145 (2009).

24 Deborah L. Rhode, The Subtle Side of Sexism, 16 COLUM. J. GENDER \& L. 613, 620 (2007).

25 See Cecilia Ridgeway, Framed By Gender 104 (2011); Cecilia Ridgeway \& Shelley Correll, Motherhood as a Status Characteristic, 60 J. SOC. IssuES 683, 683 (2004) [hereinafter Motherhood]; Stephen Benard \& Shelley J. Correll, Normative Discrimination and the Motherhood Penalty, 2 GENDER \& SOC'Y 616, 617 (2010).

26 Nancy Reichman \& Joyce Sterling, Gender Penalties Revisited 57 (2004) [hereinafter GENDER PENALTIES REVISITED], available at http://www.law.du.edu/documents/directory/publications/sterling/Genderpenalties10.pdf.

27 See Acker, supra note 22, at 146.

28 Jennifer L. Pierce, Gender Trials: Emotional Lives In Contemporary LaW FIRMS 26-49 (1995). 
nated by men tended to have more traditional definitions of masculine and feminine traits, compared to firms that achieved better gender integration. ${ }^{29}$ In the male dominated firm, women were less likely to have succeeded to the same degree as their male counterparts, and they were more likely to adopt traditional feminine traits-such as being characterized as sensitive and tentative, rather than characteristics such as aggressiveness, self-confidence, and overbearance associated with men.

It need not be so. Cook and Waters' comparison of engineering and law firms shows that organizations with traditionally male orientations but with highly formulated standards for recruitment and promotion may be hospitable to women. ${ }^{31}$ They found women's chances for representation and advancement were greater in engineering organizations that had explicit job descriptions and specified, written criteria for promotion that were then followed by interviews with teams of engineers who made recommendations for promotion. ${ }^{32}$ Women's chances were far less in law firms with more casual, less well defined, and informal structures. ${ }^{33}$ In other words, the transparency of both recruitment and promotion in the engineering firms eliminated a lot of the subjective discretion that was hidden in the decision-making processes found in the more collegial and informal law firms that relied more heavily on individual judgments of the lawyer partners. The types of governance structures help explain some of the observed differences. Engineering firms are governed by the use of formal contracts and are more likely to be subject to government legislation and regulation, while law firms are more autonomous and self-governing. Subject to more oversight, engineering firms are more likely to em-

29 Robin J. Ely, The Power in Demography: Women's Social Construction of Gender Identity at Work, 38 ACAD. MGMT. J. 589, 625-27 (1995).

$30 I d$. at 592, 613, 623. For additional studies of perceptions of women in male dominated organizations rather than gender integrated organizations, see Alison. M. Konrad \& Barbara A. Gutek, Theory and Research on Group Composition: Applications to the Status of Women and Ethnic Minorities, in INTERPERSONAL PROCESSES 98-100 (S.Oskamp \& S. Spacapan eds., 1987); F.Y. Martin, Group Sex Composition in Work Organizations: A Structural-Normative Model, in 4 Research In The Sociology Of Organizations 311-314 (Samuel B. Bacharach \& S.M. Mitchell eds., 1985); Amy S. Wharton, The Social Construction of Gender and Race in Organizations: A Social Identity and Group Mobilization Perspective, in 10 RESEARCH IN THE Sociology OF ORGAnizATIONS 79 (P.S. Tolbert \& S. Bacharach eds., 1992); Janice D. Yoder, Rethinking Tokenism: Looking Beyond Numbers, 5 GENDER \& SOC'Y 178, 189-90 (1991); Lynn Zimmer, Tokenism and Women in the Workplace: The Limits of Gender-Neutral Theory, 35 SoC. PROBLEMS 64, 67 (1988).

31 Clarissa Cook \& Malcolm Waters, The Impact of Organizational Form on Gendered Labor Markets in Engineering and Law, 46 SOC. REV. 314 (2002).

32 Id. at $329,332$.

33 Id. 
brace more formalized procedures. ${ }^{34}$ In general, when subjective decision making is replaced by more formalized and transparent procedures for hiring, evaluation and promotion, explicit forms of gender segregation and wage inequality are reduced.

\section{COLORADO STUDIES}

\section{A. Gender Penalties}

Our studies for the Colorado Women's Bar Association began with a purposive, matched sample of 100 lawyers in the Denver metropolitan area. The sample was designed to represent male and female lawyers in large, medium, and small firms and included managing partners, senior partners, junior partners, and associates with at least 5 years practice experience. In addition, we included a group of lawyers referred to as "migrants," lawyers who made at least three job moves, although many had made more. The sampling design enabled us to consider both legal careers and in-depth pictures of the contexts where our respondents worked (large, medium and small private firms, as well as government and corporate counsel). Our format for the interviews consisted of career histories. We started by asking lawyers when they knew they wanted to go to law school, where they went to undergraduate college, where they attended law school, and every career move they made from law school graduation until our interviews with them (conducted between 1996 and 1998).

Our interviews took place in an environment of some significant structural change in legal practice that coincided with more women entering the profession. ${ }^{37}$ Law firms were rapidly moving from client service to client production. ${ }^{38}$ In line with the new models of practice, firms had begun to introduce new statuses, including the now commonplace non-equity partner, as well as lengthening the time to promotion. ${ }^{39}$ They had also begun to centralize their decision making in committees that were less than transparent and with few women in-

34 See id. at 334.

35 See William T. Bielby \& Denise D. Bielby, Cumulative Versus Continuous Disadvantage in an Unstructured Labor Market: Gender Differences in the Careers of Television Writers, 19 WORK \& OCCUPATIONS 366 (1992); Barbara F. Reskin \& Debra McBrier, Why not Ascription? Organizations' Employment of Male and Female Managers, 65 AM. SOC. REV. 210 (2000).

36 Cathlin Donnell, Joyce Sterling \& Nancy Reichman, Gender Penalties: The Results of the Careers and Compensation Study, COLORADO WOMEN's BAR ASs'N (1998) [hereinafter Gender Penalties] (on file with authors).

37 See Recasting, supra note 13 , at 928.

38 See Marc Galanter \& Thomas Palay, Tournament of LaWyers: The TRANSFORMATION OF THE BIG LAW FIRM 120 (1991).

39 See Sticky Floors, supra note 21, at 43. 
cluded as members. ${ }^{40}$ We identified each change as having the potential to adversely affect the advancement of women in the profession. Our analysis pointed to the need for women to look hard at how they were building professional relationships inside and outside the firm.

New Statuses - At the time of our interviews, law firms were beginning to create new rungs on the ladders for advancement as well as alternative tracks that research suggests place women in chronic holding patterns for advancement. Instead of the simple one-tier structure of "associates" and "partners" found in the original "Cravath" model, a new trend appeared in law firms that added tiers of partnership: both "non-equity" (salaried partners) and "equity partners."." Ironically, this restructuring of law practice began just as women accumulated the seniority to take advantage of the old system. Unlike in the old system, where the criteria for promotion (tenure) were relatively clear, the requirements for achieving these new statuses were far more difficult to grasp in more than a general sense. Our associate respondents claimed that they felt that they were aiming at a "moving target." ${ }^{43}$ What they would actually achieve once they arrived at their new status also remained a mystery. One of our respondents was surprised that his "success" of being named a non-equity partner was being able to participate in the downside of profits without any of the upside. ${ }^{44}$ New statuses in law also included a reformulated "of counsel" position, more use of "contract lawyers," and "staff lawyers"- position often described as good for women since it was not associated with ambiguous and harder to obtain criteria for advancement. Since our initial research, a third type of hybrid partner status has emerged, the Income Equity Partner, where an annual salary contributes to most, but not all, of the attorney's compensation. ${ }^{45}$

40 See id. at 42.

41 See Robert Swaine, The Cravath Firm And ITs Predecessors: 1819-1948 1-9 (Lawbook Exch., Ltd. 2007); Robert L. Nelson, Practice and Privilege: Social Change and the Structure of Large Law Firms, 6 LAW \& SOC. INQUIRY 97 (1981); Wayne K. Hobson, Symbol of the New Professions, in The New High Priests: LaWyers in Post-Civil War America 3 (Gerald W. Gawalt ed., 1984).

42 See Sticky Floors, supra note 21, at 43.

43 Confidential Interviews by authors (on file with authors).

44 Id.

45 According to the NAWL Survey of AmLaw 200 firms, a new form of law firm has appeared: the "mixed-tier" firm, where a subset of equity partners are identified as "fixed-income equity partners." Fixed-income equity partners make a capital contribution to the firm, similar to other equity partners, but receive most of their compensation in the form of a fixed annual salary and/or a performance-based bonus. These individuals do not have the same voting rights as equity partners and have little to no governance authority. While NAWL questions the validity of this new status, they report that this form of partner has been growing. As of 2012, $15 \%$ of firms are classified as a mixed-tier structure. The 2011 NAWL Survey found that women constituted $37 \%$ of fixed-income equity partners. NAWL 2012, supra note 12, at 13-14. 
The structures of decision making were changing at this time as well. Historically, the partnership voted as a whole on matters of compensation and promotion. By the time of our interviews, many of the firms had become, limited liability companies (LLC) and much of that work had been delegated to centralized decision-making committees. Interestingly, the norms of universal participation, like the introduction of new statuses, occurred as more women were becoming partners. ${ }^{46}$ The "Young Turks" were behind the change, arguing that profits should be shared primarily with the biggest producers regardless of tenure and experience. ${ }^{47}$ However, the changes did little to change the discretionary nature of compensation and promotion decisions, according to our respondents. Decisions remained hidden and individually negotiated. ${ }^{48}$

Our interview respondents also helped us to unpack the compensation process, to a degree, and exposed ways in which "objective" criteria such as billable hours were built around gender norms that made them anything but objective. ${ }^{49}$ Billable hours do not grow on trees that associates can easily harvest. Billable hours depend on assignments. High profile assignments also are the way for women to be noticed within the firm. Although good assignments were the key to success, the distribution of assignments was, and still is, socially constructed in a world heavily influenced by gender stereotypes; for example, about a woman's ability or willingness to travel, despite her hard work on a case. One of our respondents described what happened after a big operational accident occurred on a Friday afternoon:

I worked all Friday night, all day Saturday, Saturday night pumping out this memo and the senior partner flew to the scene. On Saturday night she called me at the office and asked me for the phone number of a junior guy associate in our section who was one of the good old boys. She wanted him to fly out to the site of

46 See Gender Penalties, supra note 37, at 18.

47 Sticky Floors, supra note 21, at 42.

48 JoAn C. Williams \& Veta T. Richardson, The Project For AtTorney Retention, Minority Corp. Counsel Ass'N, New Millenium, SAme Glass Ceiling? The IMPACT OF LAW FIRM COMPENSATION SYSTEM ON WOMEN (2010). In their recent study, Joan Williams and Veta Richardson, address a number of questions about compensation systems, including who actually makes the compensation decisions. They discovered that the most common practice was to have a management or executive committee make the overall compensation decisions. The next most common practice was to have a separate compensation committee set overall compensation levels. Only $7 \%$ or fewer of the firms represented in their study indicated that partners had a vote on compensation.

49 Confidential Interviews, supra note 44. 
the accident to drive the work with the government guys and try to figure out what was going on...

The partner never even thought about asking her if she wanted to go to the accident site and manage the accident. ${ }^{51}$ Other respondents described situations when cases were not assigned to them because the supervising attorney thought that a client was too tough or too sexist for a woman lawyer to handle. Still others reported losing assignments once they announced they were pregnant because supervisors assumed that they would not be available to work when they might be needed, even though they also announced a specific timeline for their leave and return. ${ }^{52}$ Simply put, without assignments it was difficult for associates to bill hours. The problem was thrown back at women, for instance, when one male partner observed that his firm had "bad luck" with pregnancy.

Working directly with clients was an important measure of both "potential" and performance. But, first you had to get the assignments and then credit for the work that you did. The associates we interviewed were often uncertain about how credit was assigned and that what credit they did receive was at the discretion of the supervising attorney.

Building a "book of business" was the key to promotion for the lawyers we interviewed and, here too, the process appeared highly influenced by gender. Usually these books of business were calculated based on collecting substantial fees, $\$ 250,000$ at the beginning of our study, and easily $\$ 300,000$ by the end of the second interviews. Again, to build a solid book of business, lawyers needed meaningful work, as well as opportunities to meet clients and handle communication with them directly. This work often depended on having a senior partner who looked out for your well-being. However, many women reported that mentors like this were hard to find as they were primarily white, male partners who were drawn to white male associates who were more like them, and easier to take under their wings and set them up to begin the progression up the ladder. ${ }^{56}$

\footnotetext{
$50 \quad$ Id.

51 Gender Penalties, supra note 37, at 43.

52 Numerous respondents talked about incidents related to pregnancies. Confidential Interviews, supra note 44.

53 Recasting, supra note 13 , at 924.

54 Numerous respondents reported that they did not know how credit was distributed. Confidential Interviews, supra note 44.

55 See Gender Penalties, supra note 37, at 30. More recently, the NAWL Survey seems to indicate that a modest book of business among the AmLaw 200 is at least $\$ 500,000$. NAWL 2012, supra note 12 , at 17.

56 See Gender Penalties, supra note 37, at 51-58.
} 
The method by which firms evaluated a lawyer's book of business introduced new problems for lawyers who took parental leave. Many firms had adopted a three year average. While in theory, a running average can smooth out bumps and offer a more stable picture of performance; it can be a problem when it does not account for time off from work. As one senior partner told us, when a "star" woman in the firm had a child and did not work for three months she was evaluated as not meeting billable expectations that assumed a twelve month time frame. ${ }^{57}$ Although she jumped back into work once she returned to the firm, she could not bill enough hours to recover for the three month absence. That deficit continued to be incorporated into her evaluation for three years. ${ }^{58}$ Another of our respondents described how the three year average haunted her as she attempted to negotiate salary for a lateral move. She took a few months off when she had a child and her book of business reflected that absence that year. When she was negotiating her move, the new firm did "not" annualize her collections to project what she would have collected had she been working full time for that particular year and, thus, her book was worth considerably less than if she had been working for all of the thirty-six months. She was unable to negotiate compensation commensurate with her real value.

Because of the uncertainties associated with measuring potential and performance, and the importance of good mentors, we concluded our analysis of Gender Penalties with recommendations that lawyers take the idea of social capital seriously. Social capital consists of individuals' ability to draw on relationship networks for establishing or expanding support. Relationships were key both inside and outside the firm and it was clear that young women lawyers needed to become more strategic about making those connections. Ideally, the junior associate would build social capital by getting to know other lawyers within the firm and over time, expanding that network beyond the firm to lawyers working the opposing side of a case, and eventually to include clients and potential clients. We learned that men and women worked that process of building social capital differently. A male partner with a lot of social capital would be described as a rainmaker, "the kind of guy who can walk into a bank, stand in line and walk out with a new client." ${ }^{, 60}$ Women tended to describe their relationship-building with clients as "care and feeding," checking in with clients, insuring that they were satisfied with the legal work they were receiving. Al-

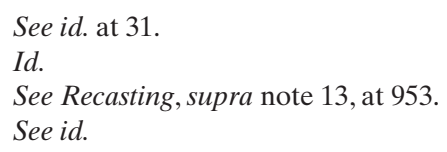


though this form of client service often resulted in clients coming back with more business, it was not as highly regarded as bringing in new business. Moreover, when work was done for existing clients, the original contact often received credit for some portion of the fees collected, even if he was no longer involved in the cases. Women appeared to have far fewer opportunities for rainmaking. ${ }^{61}$

We recommended that lawyers accumulate more social capital by expanding their networks both inside and outside of the firm. ${ }^{62}$ These connections could provide more meaningful work inside the firm, more opportunities to build business, and better access to the discretionary decision-making that was determining their futures. And, as importantly, we recommended that lawyers look closely at how their social capital was being valued. Building social capital is not enough if it is evaluated with gendered criteria.

\section{B. Gender Penalties Revisited ${ }^{63}$}

After Gender Penalties was published, the CBA conducted a new economic survey in 2000 (income reflected for 1999). ${ }^{64}$ We expected to see at least a narrowing of the gender gap in earnings but were surprised to discover that the gap had, in fact, increased in some sectors of legal practice. Although the overall gap had improved by one percent since 1994-full-time women earned sixty cents to the dollar earned by full-time men-the gap increased for women with more years of experience. ${ }^{65}$ Colorado women lawyers were not unique. After 15 years of practice, University of Michigan Law graduates showed very similar gaps in income.

61 See id. at 945.

62 For further discussion of social capital theory, see Pierre Bourdieu, The Force of Law: Toward a Sociology of the Juridical Field, 38 HASTINGS L.J. 805, 820 (1987); James S. Coleman, Social Capital in the Creation of Human Capital, 94 AM. J. Soc. SuPp. S95 (1988). For a discussion of social capital in legal careers see John Hagan et al., Cultural Capital, Gender, and the Structural Transformation of Legal Practice, 25 LAW \& SOC'Y REV. 239 (1991); Raising the Bar, supra note 18, at 728; Hilary SOMMERLAD \& PETER SANDERSON, Gender, CHOICE, \& COMMITMENT: WOMEN SOLICITORS IN ENGLAND AND WALES AND THE STRUGGLE FOR EQUAL STATUS (1998).

63 See Gender Penalties ReVisited, supra note 26.

64 Colorado BAR Ass'N 2000 ECONOMIC SuRvey (2000) (original study on file with authors).

65 See id.

66 See Mary C. Noonan et al., Pay Differences Among the Highly Trained: Cohort Differences in the Male-Female Earnings Gap in Lawyers' Salaries, 13 (Nat'l Poverty Ctr Working Paper Series, No. 03-1, 2003), available at http://www.npc.umich.edu/publications/ working_papers/paper1/03-1.pdf. Additional studies of the gender gap in pay include: J. Dixon \& Carroll Seron, Stratification in the Legal Profession: Sex, Sector, and Salary, 29 LAW \& Soc'Y REV. 381 (1995); Joni Hersch, The New Labor Market for Lawyers: Will Female Lawyers Still Earn Less?, 10 CARDozo Women's L.J. 1 (2003); Fiona Kay \& John Hagan, The Persistent Glass 
Fortunately, we received additional funding to re-interview the same 100 respondents we had interviewed five to seven years earlier to learn how their careers had evolved since we last talked to them. Our interviews resulted in hundreds of pages of transcripts, formal reports and published articles based on these data. ${ }^{67}$ We discovered that almost sixty percent of the lawyers had changed positions since they were first interviewed. ${ }^{68}$ And, most significantly, the women we had identified as the most high-powered were leaving law all together.

A major finding was that the pipeline of women lawyers was leaking at all levels. Although there was general discussion in the popular press and professional journals about the early exits of women, we found that women were leaving law not just early in their careers, but well after they had become partners and well before retirement. Not only did women lawyers move more frequently than men and earlier in many cases, they were more likely to make a move that involved a reduction in earnings. After completing our second round of Gender Penalties interviews, we discovered that almost onethird of the women who graduated from law school in the 1970s had retired from the practice of law. ${ }^{69}$ Forty percent of the women who graduated in the early 1980s had left law primarily to begin new careers in business or non-profits. ${ }^{70}$ In an important contrast, not one man in a similar cohort had decided to exit from law practice. Moreover, despite the popular press about professionals opting out, the youngest women lawyers in our study had not made decisions to leave law practice and return home to raise children. ${ }^{71}$ Instead, they were forging new career paths within their legal careers, oftentimes moving from larger firms to smaller ones or starting up their own firms altogether.

Again, in this study, we found measures of productivity to be highly gendered. In this work, however, we were able to take this a bit further to expose how the gendered distribution of firm resources created barriers for women's success. We learned that senior women did not necessarily have the same level of support for their work from

Ceiling: Gendered Inequalities in the Earnings of Lawyers, 46 BRIT. J. SOC. 279 (1995); David N. Laband \& Bernard F. Lentz, Is There Sex Discrimination in the Legal Profession? Further Evidence on Tangible and Intangible Margins, 28 J. HuM. RESOURCES 230 (1993); Karen Robson \& Jean E. Wallace, Gendered Inequalities in Earnings: A Study of Canadian Lawyers, 38 CAN. REV. SoC. 75 (2001).

67 Recasting, supra note 13; see Sticky Floors, supra note 21, at 33.

68 See Sticky Floors, supra note 21, at 33.

69 See id. at 41.

70 See id.

71 See id.

72 See id. at 58. 
paralegals or young associates. They invested their time in training new associates hired by the firm, readily accepting these assignments as demonstration that they were team players, and spent many, often non-billable hours working with these younger associates until they could carry out assignments on their own. ${ }^{73}$ However, once these new associates became valuable to the firm, they sought out work, not from the female partners who trained them, but from powerful senior males in the firm who had invested little. Female partners told us that associates would simply drop their work when a male partner asked them to do something for them. Even women who acquired a solid book of business found that they were unable to staff the business, because they kept losing the talented associates they trained to more powerful males within the firm. ${ }^{74}$ It was hard to blame the associates for hitching their careers to the more powerful in the firm. Still, the consequences for women's leadership were enormous as the continuous struggle for firm resources often drove women out of the firm and sometimes out of private law practice.

The findings of this study also reinforced the gendered nature of commitment. Commitment is readily recognized as the soft, subjective variable that determines compensation and advancement. A committed lawyer is assumed to be a good and valuable lawyer. Over the course of our two studies, we learned that commitment was synonymous with availability to work whenever necessary - day or night, weekends, etc., regardless of other responsibilities, and despite firm talk of flexibility and family-friendly environments. Following the work of Joan Williams, the ideal lawyer does not have a family or has a spouse/significant other at home taking care of private demands and can be present and visible at the firm at all times. ${ }^{76}$ Women's commitment was often challenged based on their availability. An egregious example from one of our respondents made the point. She announced to her team at the firm that she would be getting married in six months. Her supervisor publicly berated her for not thinking of the firm first as they might need her for a closing that might occur at that

73 See id. at 57-58. In addition, the National Association of Women Lawyers annual survey is supportive of our finding in Colorado. Women bill fewer hours than men (although there is less than a 50 hour/year difference). However, they find that women work more total hours than men. NAWL 2012, supra note 12, at 5.

74 Sticky Floors, supra note 21, at 57-58.

75 Id. at 61-62. In a number of firms where we interviewed talented senior women, we heard stories of how they were unable to staff their cases, despite having plenty of business. We were told that junior associates preferred to work for senior male partners, rather than a senior female partner.

76 See Williams, supra note 23, at 4-6, 70. 
time. She was both embarrassed and angered at the response and decided to leave the firm as a result of the incident.

Availability, we learned, is as much a product of impression management as the more subjective commitment. Men, according to our respondents, were better able to create the impression of visibility without actually being physically present. Male respondents talked about leaving their office door open, with lights on and leaving a jacket hanging visibly in the office - the appearance meant to convey the message 'they will be right back.' Indeed, when they left during the day to attend to a private matter, male lawyers told us that their colleagues simply assumed they were off at a meeting. Women, particularly those with children, worried more about getting work done in the hours available to them and would report that when they go to work, they would go into their office, close the door, and eat lunch at their desk, all to be able to get as much work done as possible before they had to head home for their second shift. Unfortunately, the symbolic message to the firm was either that she was not available or worse, not collegial. When a woman left early, it was often assumed that she was going to take care of children, whether or not that was case.

One of the recurrent themes that emerged from our research was that when women had a grievance with the firm, whether it was about pay, promotion, or assignments, they did not speak up to the partners or senior management. Women who managed to get a part-time arrangement or some "deal" around taking time off were afraid to complain, thinking this would lead to the firm taking a second look at their arrangement. Women were afraid to rock the boat in what they already perceived as treacherous waters. To find that women don't ask is not to place the blame on the shoulders of women. Rather, it remained clear that for all sorts of gendered reasons, women were not taking that step. Too often, women just left.

A corollary to women not asking or not complaining is that when women secured an arrangement to work a flex schedule that gave them a lower billable hour requirement, they ended up actually working full-time and not getting paid for the entire number of hours they billed. Repeatedly, we heard from women that they had decided to work $80 \%$ time, taking an associated pay cut. When we asked whether they were able to work only $80 \%$, universally we heard responses to the effect that they still worked full-time hours, but no longer worried about making their billable hours. Surprisingly, these women were working full-time billable hours without being paid commensurate for

77 See Gender PENALtiEs ReVISITED, supra note 26, at 53. 
their time. It is also the case that the firm never came to them and told them they were working too many hours for what they were being paid. Women with some form of part-time arrangement were also unwilling to ask for a raise in their compensation. Respondents told us that they worried their arrangement would become visible and it would attract questions about their schedule.

Most troubling was that these, perhaps, unintentional gender bias in assessments of productivity and commitment could become selffulfilling. Consider the following scenario. A senior partner lands a client and asks a junior partner to put together a team, adding: "This case is going to take a long while. Continuity is very important." The junior partner is looking at two senior associates, John and Jane. He knows that women turn over more rapidly than men. Indeed, he has just heard a presentation that confirms that women leave early. So he thinks, "if I put a woman on this case, I may end up in trouble." In the end, John gets the work on the case and Jane works on "something else." After a while, Jane says "I'm not going anywhere with this firm" and she leaves. The junior partner thinks, "I told you so!" Or, Jane announces she is pregnant. Immediately she notices that both the quantity and quality of work dries up. Six months later she has her baby and takes maternity leave. Somewhere around four weeks into her leave, she starts to think about work and, in particular, the last six months or so. She wonders whether she will ever get back on track and thinking that she might not, she decides she might want to stay home for a while-those diapers are looking pretty good compared to twiddling her thumbs in the office. The partners say: "We told you so!"

After completing our Colorado research into the careers of female and male lawyers, we wrote reports on our findings, presented the findings to the Women's Bar, the Colorado Bar Association, presented seminars to managing partners, and talked to the Fellows of the American Bar Foundation and academic colleagues. We thought we had contributed to the process of demystifying gender bias. We discussed where we had discovered sources of hidden bias, and how the profession could move forward and implement changes that would lead to equity as well as equality within the practice of law. Our recommendations focused on transparency and greater reflection on decisions. We suggested that senior partners needed to be more mindful of the biases that might be influencing the distribution of assignments and other inputs to lawyer's productivity. We made presentations to law firm managing partners and encouraged them to "test" their compensation systems to see if they were as fair as they thought. We suggested that it would be helpful to open up the dialogue about what "counts" for compensation and promotion. Discussions about work- 
life integration ought not be forbidden territory, we counseled. Too often and with good reason, women were reluctant to explore their ideas about creating work-life balance for fear that just the discussion might lead to their being excluded from meaningful work or from consideration for more promotion. There was no rational planning either from the individual or the organization on how to deal with short career interruptions.

\section{AJD}

Our analysis of the AJD data demonstrated that our optimism that the gap would narrow was misplaced. We examined earnings differences from two waves of data collection. ${ }^{78}$ To date, data were collected in 2002, (after 2-3 years of practice), 2007 (after 7 years of practice) and 2012 (after 12 years of practice). ${ }^{79}$ After only 2-3 years of practice, the average full-time woman earned 5.2\% less than the average full-time man. The average salary for women was $\$ 90,527$ compared to the average of $\$ 96,486$ for men, a nearly $\$ 6,000$ difference. ${ }^{80}$ At seven years of practice, the difference between the average man and woman working full time increased to approximately $13 \%{ }^{8}$ Women reported an average salary of $\$ 94,145$ compared to the $\$ 114,426$ average for men, a difference of $\$ 20,000$. $^{82}$

AJD is the first national longitudinal study of lawyers in the U.S. The respondents were drawn from a nationally representative sample of lawyers who were admitted to practice in 2000 and graduated from law school between June 1998 and July 2000. ${ }^{83}$ The sampling frame represents 18 strata by region of the country and the size of the new lawyer population for each strata. ${ }^{84}$ The sample includes all four "major" markets, those with 2,000 new lawyers (Chicago, Los Angeles, New York, and Washington, D.C.); five of the nine "large markets," those with 750 to 2,000 new lawyers (Boston, Atlanta, Houston, Minneapolis, San Francisco); and nine of the remaining smaller markets

78 See Ronit Dinovitzer, Nancy Reichman, \& Joyce Sterling, The Differential Valuation of Women's Work: A New Look at the Gender Gap in Lawyer's Incomes, 88 SOC. FORCES 819 (2009); Joyce Sterling, NANCy Reichman, \& Gabriele Plickert, Status

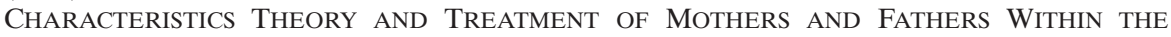
PRACTICE OF LAW (paper presented at the Annual Meeting of the Law and Society Association in Boston, MA, June 2013).

79 AJD I, supra note 2; AJD II, supra note 3.

80 Dinovitzer, Reichman \& Sterling, supra note 79, at 819.

81 AJD II, supra note 3, at 67.

82 Reichman \& Sterling, Parenthood Status and Compensation in Law Practice, 20 IND. J. GlobAl LEGAL STUD. (forthcoming Summer 2013).

83 AJD II, supra note 3, at 12.

84 Id. 
(Connecticut, New Jersey remainder, Florida remainder, Tennessee, Oklahoma, Indiana, St. Louis, Utah and Oregon). The First Wave data collection relied on a mail questionnaire fielded in May 2002 - after two to three years of practice. ${ }^{85}$ The response rate for Wave 1 was $71 \%$ (4538 valid responses). ${ }^{86}$ The Second Wave of AJD attempted to locate the entire original sample, after approximately 7 years in practice. Our response rate in AJD2 was $70.4 \%$ for those who had responded to AJD1 and $26.9 \%$ for those who had not responded to AJD1 (4160 valid responses), referred to as AJD1 nonrespondents. ${ }^{87}$ Finally, a third wave was fielded in 2012 (12 years into practice). The data from the Third Wave are not yet available for analysis.

The AJD study is unique for the use of a representative sampling frame, the addition of an oversample of lawyers of color, and the longitudinal nature of the study that allows researchers to follow respondents' careers as they develop and mature. Other studies have been able to conduct cross-sectional longitudinal designs - where the sample population is sampled overtime, but not necessarily the same respondents. The AJD data isolates both change patterns of groups within the sample overtime, and also trace the changes made by individuals within the sample.

For our analysis of the first wave data, we were joined by Professor Ronit Dinovitzer to focus directly on the gap and the factors that would help it. Using a statistical modeling technique, decomposition, we sought to explain how much of the gap could be explained by differences in the work profiles of men and women (endowments) and how much could be explained by differences in the rewards that men and women receive for the endowments they have. Endowments included standard measures of human capital (law school GPA, elite status of law school attended and key demographics, including marital status and whether or not the lawyer was a parent) as well as measures of work setting (size of firm, market) and experience (work hours). Overall, we were quite successful in predicting salary. Nearly three quarters of the variance in salary was explained by the variables we included in our models, an exceptionally large result in the social sciences. ${ }^{88}$ Applying these same variables to our examination of the gap in salary, we were able to determine that only $15 \%$ of the gap could be explained by the fact that women and men had different endowments (demographics, work experience and work setting). Fully $75 \%$ of the gap was attributed to women being valued

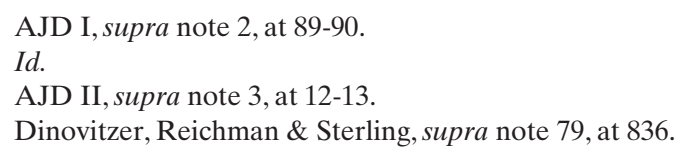


(rewarded) less than men for their endowments. Statistically, this $75 \%$ of the gap is considered unexplained, as we cannot account for the value differences we observe. Experimental data confirms ways in which women's work is devalued in comparison to men, ${ }^{89}$ particularly when they are assumed to be less of a "fit" for the task at hand.

Our analysis of the gap after 7 years of practice took a slightly different turn. Using a model similar to that which we used in our analysis of the first wave of AJD data, we again found success predicting income and, again, gender remained a consistent factor after entering controls for demographics, and work setting. For this analysis, we adopted a framework of "cultural superschema," specifically, the cultural construction of performance attached to gender and parenthood. These cultural schema profoundly influence the assessment of competence, commitment, and performance, and can create barriers to the advancement of workers who are culturally defined as less worthy. ${ }^{90}$ The evaluation of potential and actual performance becomes a "self-fulfilling prophesy" when certain status actors (male lawyers) are given more opportunities to participate and to demonstrate their competence in the workplace than other status workers. ${ }^{91}$

Over the last decade, the literature on status expectations has shifted attention away from a simple gender distinction to explore the concept of parenthood as an important status in its own right. ${ }^{92}$ Too often, we assume that fathers are motivated and committed to work while mothers, given their druthers, prefer to stay home and take care of children. These role stereotypes become important "background" for assessments that view mothers as less status-worthy and less competent than fathers." In these cases, fathers might receive a "daddy bonus" and women a "mother penalty." Research shows that mar-

89 See Virginia Valian, Why So Slow? The Advancement of Women (1999); Madeline E. Heilman \& Tyler G. Okimoto, Why are Women Penalized for Success at Male Tasks?: The Implied Community Deficit, 92 J. APPLIED PSYCHOL. 81 (2007)

90 See Motherhood, supra note 25, at 684-685; Shelley J. Correll \& Stephen Benard, Biased Estimators? Comparing Status and Statistical Theories of Gender Discrimination, 23 ADVANCES IN GROUP PROCESSES 89 (2006).

91 Correll \& Benard, supra note 91 , at 91.

92 See RIDGEWAY, supra note 25, at 47-49, 149-51; Correll \& Benard, supra note 91, at 93; Michelle J. Budig \& Melissa J. Hodges, Difference in Disadvantage: Variation in the Motherhood Penalty across White Women's Earnings Distribution, 75 AM. Soc. Ass'N 1 (2010); Motherhood, supra note 25, at 684 .

93 See Shelley J. Correll, Stephen Benard \& Ian Paik, Getting a Job: Is There a Motherhood Penalty?, 112 AM. J. Soc. 1298 (2007); Motherhood, supra note 25, at 684-85.

94 Melissa J. Hodges \& Michelle J. Budig, Who Gets the Daddy Bonus?: Organizational Hegemonic Masculinity and the Impact of Fatherhood on Earnings, 24 GENDER \& SOC. 717 (2010); J. Hersch \& L. Stratton, Household Specialization and the Male Marriage Wage Premium, 54 IND. \& LAB. REL. REV. 78 (2000); Sanders Korenman \& David Neumark, Does Marriage 
ried men earn higher wages than unmarried men. ${ }^{96}$ Given prevailing stereotypes, we expected that male lawyers without children would be more highly valued than female lawyers, mothers, or even fathers. Contrary to our hypothesized expectations, we found that parenthood status did not have a significant effect on credentials, orientation to work, hours or even where lawyers practice law. ${ }^{97}$ We found that fathers had more opportunities to work with high-profile clients than both mothers and women without children, but were no more likely than men without children. In sum, gender matters more than parenthood when predicting compensation and hours worked. ${ }^{98}$ The one deviation from the overall trend was a clear motherhood difference in billable hours. Mothers billed less hours than men and women without children. ${ }^{99}$ Given the gendered opportunity structures we identified in our earlier studies, this may not be too surprising.

The data from wave 2 of AJD offered a preliminary look at the distribution of bonuses, an increasingly important component of compensation for some lawyers. For those respondents who reported a bonus we found that women were significantly more like to receive either no bonus or a bonus less than $\$ 10,000$, while men are significantly more likely to receive bonuses over $\$ 10,000$. This last finding will need further validation once we are able to analyze the Wave 3 data. In particular, the anomalous findings and findings on bonuses are important, since they tend to be not easily observed in reported research.

Really Make Men More Productive?, 26 J. Hum. Resources 282 (1991); Martha Hill, The Wage Effects of Marital Status and Children, 14 J. HuM. RESOURCES 579 (1979).

95 See Motherhood, supra note 25, at 684-85; Jennifer Glass, Blessing or Curse? WorkFamily Policies and Mothers' Wage Growth over Time, 31 WORK \& OCCUPATIONS 367 (2004); Amy J.C. Cuddy, Susan T. Fiske \& Peter Glick, When Professionals Become Mothers, Warmth Doesn't Cut the Ice, 60 J. Soc. Issues 701 (2004); Michelle J. Budig \& Paula England, The Wage Penalty for Motherhood, 66 AM. Soc. REV. 204 (2001); see also Jane Waldfogel, The Effect of Children on Women's Wages, 62 AM. Soc. REV. 209 (1997); Shelly Lundberg \& Elaina Rose, The Effects of Sons and Daughters on Men's Labor Supply and Wages, 84 REV. ECON \& STAT. 251 (2002); David Neumark \& Sanders Korenman, Sources of Bias in Women's Wage Equations: Results Using Siblings Data, 29 J. HuM. Resources 379 (1994); Jane Waldfogel, The Family Gap for Young Women in the United States and Britain: Can Maternity Leave Make a Difference?, 16 J. LAB. ECON. 505 (1998); Jane Waldfogel, Understanding the 'Family Gap' in Pay for Women with Children, J. ECON. PERsP. 137 (1998); HeAther Joshi \& MARIE-Louise NeWELl, UNIVERsity OF WARWICK INSTITUTE FOR EMPLOYMENT RESEARCH, PAY DIFFERENTIALS AND PARENTHOOD: ANALYSIS OF MEN AND WOMEN BORN IN 1946 (1989).

96 See Rebecca Glauber, Race and Gender in Families and at Work, 22 GENDER \& SOC'Y 9 (2008); Eng Seng Loh, Productivity Differences and the Marriage Wage Premium for White Males, 31 J. HuM. RESOURCES 566 (1996).

97 See Reichman \& Sterling, supra note 83.

98 See WiLliAMS \& RichARDSON, supra note 49, at 18-19.

99 See Reichman \& Sterling, supra note 83. 
Our Colorado research, the results of AJD, research by a number of scholars of the legal profession and the NAWL 2012 Annual Survey results, all indicate that women lawyers have not made the progress that scholars predicted ${ }^{100}$ and others said it would simply be "a matter of time." However, gender disparity persists. Firms have not eliminated the gaps in income and promotions that we identified over the last 15 years. $^{101}$ Women are decreasing as a percentage of law students. ${ }^{102}$ Women continue to leave firms earlier and more frequently than men. ${ }^{103}$ The "implicit gender bias" "104 remains fueled by structural changes such as those discussed earlier in this article.

These structural features have worked to the disadvantage of many of the associates entering the marketplace during the last four years. In particular, women and lawyers of color have experienced implicit bias associated with the changes.

\section{RECOMMENDATIONS}

Despite twenty years of research that documents gender bias in the legal profession, it would be fair to say that change has come slowly. It is time to pick up the pace. We have tried endurance, now we need to sprint. Our training plan is modified, in part, from the eight steps to implement a feminist perspective developed by our dear, late colleague, feminist legal scholar Professor Ann Scales. Professor Scales proposed that we adopt an outsider perspective ${ }^{106}$ with the optimism that our recommendations will lead to insider social change.

"Eschew Neutrality:" 107 Professor Scales reminds us that neutrality makes no logical sense in U.S. jurisprudence. If a position were really neutral, it "draws no lines, nor authorizes any action according to differences among situations." ${ }^{108}$ Of course, as Professor Scales

100 See Deborah L. Rhode, A.B.A.Comm'n On Women In The Profession, The Unfinished AgEndA: Women And THE LEgAl PROFESSION (2001).

101 See Gender Penalties, supra note 37.

102 NALP FOUND., supra note 8 , at 7.

103 NAWL 2012, supra note 12, at 8-9.

104 See generally Justin D. Levinson \& Danielle Young, Implicit Gender Bias in the Legal Profession: An Empirical Study, 18 DUKE J. GENDER L. \& POL'Y 1 (2010) (discussing implicit gender bias). The authors indicate that their use of the term "implicit gender bias" is also referred to as "unconscious gender bias."

105 Ann Scales, Feminist Legal Method, Not So Scary, 2 UCLA WoMEN's L.J. 1 (1992). We dedicate this piece to the memory of our late colleague Ann Scales, who passed away on June 24, 2012, much too early. She coined the term feminist jurisprudence in Ann Scales, The Emergence of Feminist Jurisprudence: An Essay, 95 YALE L.J. 1373 (1986).

106 See generally Feminist Legal Method, supra note 106.

107 Id. at 10 .

108 Id. 
makes clear, "law is all about drawing lines, contrasting behaviors, and making classifications." ${ }^{, 109}$ Thus, adopting neutral principles as a method to eliminate gender bias in the profession, in a system that is designed to make distinctions, would be to accept the "pretense of neutrality" - a position that has historically created obstacles for women. ${ }^{110}$ According to the Scales Method it is not possible to adopt a legal rule that does not take sex into account, if we really want to eliminate gender inequality.

"Practice Solidarity:" "Professor Scales reminded us that solidarity refers to other-directedness. She implores us to think about how our decisions as professionals affect other people. It is easy to adopt rules that we think will bring about change; only to find out we have created new problems. For us, this means we need to be aware of when reforms unintentionally re-incorporate race, gender, and class within the legal environment.

A second dimension of Scale's "solidarity steps" directs us to try unfamiliar strategies that are informed by previously unheard voices. As we conceptualize change in the legal profession that will bring about gender equality, we cannot worry about our fear of failure. How do we really know if changes in methods of billing, distribution of credit, and evaluating lawyers for compensation and promotion will not enhance the quality of life of all lawyers? The Scales principle presents the possibility that "the social construction of gender could change, and that would be to everyone's benefit. Both women and men are significantly eaten up by genderization." ${ }^{112}$ We must move forward.

With these principles in mind, we recommend:

- More studies of law practice and fewer studies of lawyers.

Recognizing it is the structures of legal practice that create bias, not simply the attitudes of practitioners, we must expand systematic social scientific inquiry into how law practice and compensation actually work. Despite the abundance of studies of lawyers during the last two decades, we are missing information about how the components of compensation are constructed. The 2012 NAWL study reported that women work more total hours than men, but bill fewer hours. ${ }^{113}$ What accounts for this discrepancy? How, exactly, do lawyers accumulate the hours they report and what are the factors that influence which hours are billed and which are not? And, what about bonuses?

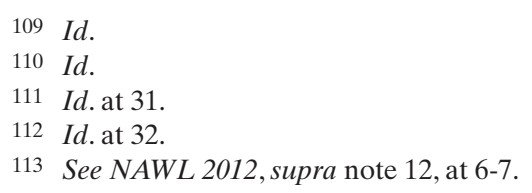


How are they calculated? We are well aware that there are rules about these. But, as socio-legal scholars we are also well aware that law in action oftentimes differs from what is on the books. More empirical research is necessary.

- Re-orient our focus away from the problems of work-family integration issues to directly address the stereotyping of women.

There can be little doubt that problems of work-family integration plague women workers at all levels. Lawyers, arguably, have more means and privilege to address these than most. Still, for so many women lawyers, the problem begins and ends with work-family dilemmas. Our forthcoming paper on compensation disparity suggests that gender is as significant, and, can be more significant than the reality of parenthood in predicting career outcomes, suggesting that implicit stereotypes continue to operate. ${ }^{114}$ We need to begin the reorientation by deconstructing the gender stereotypes.

- Law firms should be required to disclose information about gender and race of non-equity and equity partners.

You can't change what you don't observe. Law firms need to stop hiding behind privacy when responding to general questions about salary. Social science has long been able to employ data analysis without revealing identities of individuals. This situation is no different than other data collection and analysis efforts of professionals and workers in a number of occupations. The disclosure recommendations follow Scales' imperative to eschew neutrality by generating the information to challenge the neutrality premise and to deconstruct male dominance of law firm partnerships. ${ }^{115}$ The sooner we recognize there is no real neutrality, the sooner we can bring about the change to eliminate gender disparity.

To bring transparency and accountability to the area of gender discrimination in the workplace, Grand proposes that the legal profession should adopt disclosure rules similar to those required by Sarbanes-Oxley. ${ }^{116}$ Her proposal, similar to the SEC rules passed in 2003, requires companies to disclose how nominations for board seat candidates are handled. ${ }^{117}$ Such disclosure would allow new and lateral associates to decide whether they want to join particular law firms, as the provisions of Sarbanes-Oxley allow investors to decide which

\footnotetext{
114 See Reichman \& Sterling, supra note 83.

115 See generally Feminist Legal Method, supra note 106.

116 Rachel B. Grand, "It's Only Disclosure”: A Modest Proposal for Partnership Reform, 8 N.Y.U. J. LEGIS. \& PUB. POL’Y 389 (2005).

117 See Disclosure Regarding Nominating Committee Functions and Communications Between Security Holders and Boards of Directors, Exchange Act Release No. 33-8340, 81 SEC Docket 2132-83 (Nov. 24, 2003); Grand, supra note 117, at 405.
} 
companies are worthwhile for investment. She argues that it would be beneficial to require revelation of the nomination and evaluation procedures for partnership candidates. ${ }^{118}$

Another option would be to compel professional associations to require gender audits as part of professional practice and discipline individuals or firms that discriminate. ${ }^{119}$ They might adopt revisions to Rule 8.4 similar to those already adopted by Minnesota and New York. The Minnesota rule applies to all of a lawyer's activities. Under Minnesota Rule 8.4(h) it is professional misconduct for a lawyer to commit a discriminatory act that violates federal, state or local statute or ordinance and was committed in connection with the lawyer's professional activities. $^{120}$ In a call for reform of the ABA Model Rules, Lancia advocated that the ABA should adopt New York Rule 8.4(g), which is a bi-focal approach to prohibiting discrimination. ${ }^{122}$ The New York Rules of Professional Conduct both explicitly prohibit lawyers and law firms from discriminating both in the practice of law and in determining conditions of employment.

We have already seen that voluntary disclosure will not occur. In 2010, NALP briefly required law firms to disclose the percentages of women and minorities in non-equity as well as equity partnerships. However, the firms claimed partner privacy issues and threatened to

118 See Grand, supra note 117, at 391.

119 Already, this is part of the requirements of Sarbanes Oxley, and this is a potential reality for law schools, whose employment statistics have been called into question by the ABA.

120 Minn. Rule 8.4(h) provides: "It is misconduct for a lawyer to commit a discriminatory act, prohibited by federal, state, or local statute or ordinance that reflects adversely on the lawyer's fitness as a lawyer. Whether a discriminatory act reflects adversely on a lawyer's fitness as a lawyer shall be determined after consideration of all the circumstances, including (1) the seriousness of the act, (2) whether the lawyer knew that it was prohibited by statute or ordinance, (3) whether the act was part of a pattern of prohibited conduct, and (4) whether the act was committed in connection with the lawyer's professional activities."

121 Previously New York Code of Professional Responsibility DR 1-102(A)(6). New York adopted a set of rules based upon the Model Rules effect on April 1,2009.

122 Nicole Lancia, New Rule, New York: A Bifocal Approach to Discipline and Discrimination, 22 GeO. J. LEGAL ETHICS 949 (2009). The New York Rule provides that a lawyer or law firm shall not: Unlawfully discriminate in the practice of law, including in hiring, promoting or otherwise determining conditions of employment on the basis of age, race, creed, color, national origin, sex, disability, marital status or sexual orientation. Where there is a tribunal with jurisdiction to hear a complaint, if timely brought, other than a Departmental Disciplinary Committee, a complaint based on unlawful discrimination shall be brought before such tribunal in the first instance. A certified copy of a determination by such a tribunal, which has become final and enforceable and as to which the right to judicial or appellate review has been exhausted, finding that the lawyer has engaged in an unlawful discriminatory practice shall constitute prima facie evidence of professional misconduct in a disciplinary proceeding. See PROFESSIONAL RESPONSIBILITY STANDARDS, RulES \& STATUTES 308 (John S. Dzienkowski ed., 2012). 
pull out of NALP. As a result, NALP retreated from the requirement and did not change their reporting system.

- Women's Bar Associations need to create a social movement that can attack implicit bias in the legal profession.

It is not enough to document repeatedly the gap in income and promotion of women lawyers. The Women's Bar Associations should mobilize to insist that professional associations take on the responsibility of governing the gap. Women's Bar Associations could be the vehicle for implementing changes to the ABA Model Rules, which would likely influence changes in the state level. In addition, these Women's Bar Associations could spearhead implementation of a regulatory body that would ensure holding lawyers and law firms accountable to rules prohibiting discrimination in the legal profession. It is clear that we need both Model Rule updating and creation of a regulatory body in order to begin to rid the profession of disparity. Let women embrace their legal knowledge and abilities to be good lawyers! Let them innovate!

In summary, we propose: additional research to finally fill the gap in our knowledge of the inner workings of law firm practice; shifting our focus away from getting "stuck" on issues of work-family integration; and both disclosure rules and anti-discrimination rules to become an explicit provision of the Model Rules of Professional Conduct. The feminist activist agenda proposed by Ann Scales can be summed up as Ann best described it: RAISE HELL AND HAVE FUN?

123 Elie Mystal, NALP Won't Distinguish Between Equity and Non-Equity Partners: Women, Minorities and Lovers of Truth Get Angry, ABOVE THE LAW (Feb 24, 2010, 1:34 PM), http://abovethelaw.com/2010/02/nalp-wont-distinguish-between-equity-and-non-equity-partnerswomen-minorities-and-lovers-of-truth-get-angry. 